\title{
締固めた泥岩材料の水浸沈下 特性に関する基礎的研究
}

\author{
村上幸利 \\ 正会員 工博 山梨大学教授 工学部土木環境工学科（广400-0016 甲俯市武田四丁目3-11）
}

典型的な軟岩の一つである泥岩が盛土材として用いられる場合, 乾燥・湿潤の繰り返しや地下水位の 変動等によって材質の劣化が生じて, 表面沈下や膨潤の発生なら゙盛土体の安定性に係わる問題が起こり やすい。本研究では，締固めた泥岩塊材料の力学的性質や浸透機構を考虑に入れながら，水浸に伴って 発生する圧縮変形について理論の構築と解析ならびに室内実験を行った。その結果，限定された条件の もとではあるが，水浸沈下ならびに含水量の経時的変化に対して，構築した理論の妥当性を検証すると ともに，水浸沈下特性に関する幾つかの知見を得た。

Key Tords : slaking, settlement due to submergence, mudstone, embankment, unsaturated hydraulic conductivity

\section{1.まえがき}

道路建設や宅地造成に関連して各種の盛土構造物が築 造される場合に，経阁性あるいは環境保全への配虑から， 築造現場付近に分布する岩石がそのまま盛立て材料とし て用いられることが多い。しかし，その岩石が泥岩や頁 岩といった水成堆積岩あるいは凝灰角磷岩等の火砕岩で ある場合には, 安山岩などの硬岩に比べて強度的に少り, また環境変化の影響を受けて容易に脆弱化するために, 締固めが不十分な場合には, 乾燥・湿潤の繰返しあるい は地下水位の変動に伴って，長期にわたる継続的な沈下 の発生あるいは法面部での進行性崩壊等, 盛土体の安定 性に倸わる種々の問題が誘発される可能性が高い11，2． たとえば図ー 1 は，山梨県某所の沢部において最大高さ にして約 $20 \mathrm{~m}$ 盛土が泥岩塊材料(最大粒径は約 $20 \mathrm{~cm}$ )を 用いて含水量管理と密度管理のもとに転圧・築造された ケースについて, 最大盛土付近の表面で観測された沈下 量の経時的変化と日降水量の関係を表したものである. この図を見ると，日降水量にして $100 \mathrm{~mm}$ 超えるような 降雨があると，それ以降において付加的な沈下が新たに 発生している様子が分かる.このように水浸に伴って発 生する軟岩盛土の沈下は, 岩塊粒子のコラプス現象なら びに岩塊粒子自体の軟弱化に起因するとされ，水浸沈下 と呼ばれている3)。軟岩盛土の水浸沈下量を解析的に求 める方法は幾つか提案されているが，そのほとんどは非 水浸状態での圧縮試験または圧密試験を行った後に水浸 試験を行い, その試験結果の比較から盛土体の水浸沈下 を定量的に把握しようとするものであり4（5)，今まで のところ, 不飽和浸透のメカニスムを考虑して水浸沈下

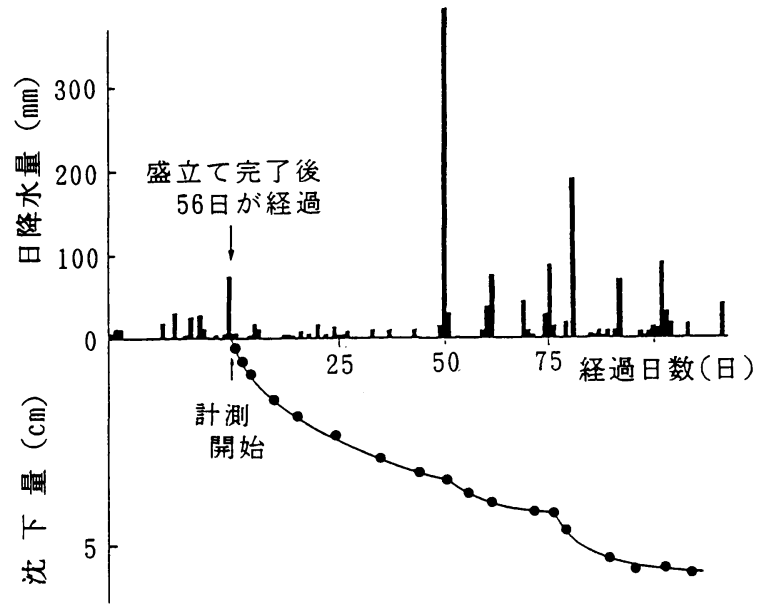

図-1 盛土表面での沈下測定の例

の経時的変化を解析的に扱ったものはないようである.

著者は，既に，泥岩や凝灰角硶岩などの軟岩を対象に して, 締固めた軟岩材料の力学的安定性に及ぼす岩の性 質と締固め度の影響について調へ，これら三者の間には 強い関連性があることを明らかにし，それに基づいて軟 岩盛土の転圧・締固め時における管理基準の設定が可能 であることを示した ${ }^{6)}$. 特にそのなかで、これまでの研 究によっても明らかにされているように，楴固めた盛土 材の水浸沈下は盛土体の間隙中に存在する空気量が少な い場合は微小であるものの, 空気量がある一定値を超え ると急激に增大することが確認されている7゙。また， の水浸沈下の進行は盛土体の水浸後において時間的な遅 れを伴い，压密沈下と類似した経時的変化をもつことが 
現場または室内試験での観測から明らかにされている5

本論においては，上記のような既往の知見を踏まえな がら, 山梨県という限定されたグリーンタフ地域に分布 する泥岩を対象として，それを盛土材料として締固めた 場合の水浸沈下特性について, 泥岩材料の基本的性質と 力学的性質および不飽和土の浸透メカニズムを念頭に置 きながら，理論および実験の両面から検討しようとする ものである。

\section{2. 水浸沈下に関する理論的アプローチ}

締固めた泥岩材料は, 塊状の泥岩片と破砕 - 細粒化し た泥岩粒子の混合体とみなすことができる，その粒度は， 楴固め以前における泥岩材の状態や締固め条件等によっ て強く影響を受ける。材料が多量の細かい泥岩粒子に混 じえて大きい泥岩塊を含有するような不均等性の高い場 合あるいは大きい泥岩塊だけでほとんどを占められるよ うな場合には，材料中の水分移動や変形挙動に関する力 学機構は極めて複雑であって，その理論的取扱いは非常 に困難になると考えられる. また前述したように，水浸 沈下は吸水による粒子自体の脆弱化と骨格構造のコラプ スに起因するとされるが，それをそのまま解析的に扱う のは無理がある。したがって，本研究においては，この 種の研究の端緒として, 粒度が比較的細かく, ほぼ均等 であるような泥岩粒子材料を静的に締固めた場合をモテ ル化して, 吸水による粒子自体の脆弱化についてはセメ ンテーションによる粒子間応力の変化によって表し，ま た水浸に伴う骨格構造のコラプス現象についてはサクシ ヨンの変化によって表すことにより, 水浸沈下現象に関 する理論的アプローチを試みる.なお，理論の取扱いの 簡粱化を図るために，1次元状態を対象にする。また， 発生ひずみ量が比較的微少であることを考虑して, 材料 の水浸に伴う有効応力変化と体積変化の間には線形関倸 が存在すると仮定する.

まず，構成関倸については,

$$
\sigma_{z}^{\prime}=\mathrm{E}_{c} \partial \mathrm{w} / \partial z=\mathrm{E}_{c} \varepsilon_{z}
$$

ここに, $\sigma_{z}{ }^{\prime}$ : 鉛直 $z$ 方向の有効応力, $\varepsilon_{z}$ : 鉛直方向の ひずみ, $\mathrm{w}$ : 鉛直方向の変位, $\mathrm{E}_{c}$ : 側方拘束状態での 変形倸数であり, 締固めた材料の飽和度によって若干変 化するが, ここでは定数として扱う。

応力関倸は, 有効応力の概念ならびに不飽和土に対す るビショップの関倸を用いることとする。

$$
\sigma_{z}=\sigma_{z}^{\prime}+\sigma_{c}^{\prime}+\mathrm{p}_{a}-\chi\left(\mathrm{p}_{a}-\mathrm{p}_{\omega}\right)
$$

ここに, $\sigma_{z}$ : 鉛直方向の全応力, $\sigma_{c}{ }^{\prime}$ : セメンテーシ ョンによる粒子間応力, $\chi$ : ビショップのパラメータ, $\mathrm{p}_{a}$ : 間隙空気圧, $\mathrm{p}_{w}$ : 間隙水圧である.なお, $\sigma_{c}{ }^{\prime}$ については，泥岩塊が本質的にもっているセメンテーシ ヨンが泥岩粒子によっても部分的に受け持たれるとして， この存在を仮定する。釣合い条件式は，

$$
\partial \sigma_{z} / \partial z=0
$$

であるので, 式(1)〜(3)を用い, サクション $\psi=\left(\mathrm{p}_{a}\right.$ - $\left.\mathrm{p}_{w}\right) / \gamma_{w}(<0)$ を考虑することによって,

$$
\begin{gathered}
\mathrm{E}_{c} \cdot \partial \varepsilon_{z} / \partial z+\partial \sigma_{c}^{\prime} / \partial z+ \\
\partial\left(\mathrm{p}_{a}-\chi \phi \gamma_{w}\right) / \partial z=0
\end{gathered}
$$

を得る. 式中の $\gamma_{w}$ は水の単位体積重量を表す. セメン テーションによる粒子間応力 $\sigma_{c}{ }^{\prime}$ を適切に評価すること は非常に難しいが，泥岩粒子が吸水によって軟弱化する ことを考えて，ここでは， $\sigma_{c}{ }^{\prime}=\left(1-\mathrm{S}_{r}\right) \sigma_{c 0}{ }^{\prime}$ と 仮定する ${ }^{8)}$. なお $\mathrm{S}_{r}$ は小数表示での飽和度であって，

$\sigma_{c 0}{ }^{\prime}$ は完全乾燥状態における $\sigma_{c}{ }^{\prime}$ である。 また, 近似 的に $\chi \leftrightharpoons \mathrm{S}_{r}$ と仮定できるので, 式(4)は,

$$
\begin{aligned}
E_{c} & \cdot \partial \varepsilon_{z} / \partial z+\partial\left\{\left(1-S_{r}\right) \cdot \sigma_{c 0}^{\prime}\right\} / \partial z \\
& +\partial\left(\mathrm{p}_{a}-\mathrm{S}_{r} \phi \gamma_{w}\right) / \partial z=0
\end{aligned}
$$

になる.ここに, サクション $\phi$ はマトリックポテンシャ ルヘッドとして, 若干の考察を行うことにより, 次のよ うに表せる.

$$
\psi=\phi_{0} \cdot \exp (-\alpha \theta)
$$

上式において， $\alpha$ は定数， $\phi_{0}$ は吸水過程での水分特性 曲線（含水比一サクション曲線）を直線近似した場合に おいて含水比 0 に対応するサクションである。また， $\theta$ は体積含水率であり， $\theta=\mathrm{n} \cdot \mathrm{S}_{r}$ （n：締固めた泥岩 材料の間隙率）の関倸がある。このようにして得られた 式(5)は, 任意の一定時刻における泥岩材料の飽和度と 発生ひずみ量の関係を表す.

一方, 不飽和状態の締固めた泥岩材料中に生じる水の 浸透について考える. まず, 鉛直方向のフラックス $\mathrm{q}_{z}$ は，次のように表せる。

$$
\mathrm{q}_{z}=-\mathrm{K} \cdot \partial \phi / \partial z=-\mathrm{K} \cdot \partial \phi / \partial z-\mathrm{K}
$$

ここに，Kは不飽和透水係数である．また， $\phi は$ 全ポテ ンシャルヘッドであり， $\phi=\phi+z$ の関倸をもつ. 連続 条件式は，

$$
\partial \theta / \partial t=-\partial q_{z} / \partial z
$$

であるので，式(6)を用いて，

$$
\begin{aligned}
& \partial \theta / \partial \mathrm{t}=(\mathrm{K} \partial \phi / \partial \mathrm{z}) / \partial \mathrm{z}=\partial(\mathrm{K}(\phi) \partial \phi \\
& / \partial z) / \partial z+\partial K(\phi) / \partial z
\end{aligned}
$$

となる．前述したように， $\theta$ は体積含水率であって，初 期間隙率を $\mathrm{n}_{0}$ とすると, $\theta=\mathrm{n} \cdot \mathrm{S}_{r}=\left(\mathrm{n}_{0}+\varepsilon_{z}\right)$ - $\mathrm{S}_{r} /\left(1+\varepsilon_{z}\right)$ の関係がある.なお, 水分拡散釈数と 呼称される $\mathrm{D}(\theta)=\mathrm{K}(\theta) \cdot \mathrm{d} \phi / \mathrm{d} \theta$ を導入すると， 式(7)は,

$$
\begin{aligned}
\partial \theta / \partial \mathrm{t}= & (D(\theta) \partial \theta / \partial \mathrm{z}) / \partial \mathrm{z}+ \\
& \mathrm{dK}(\theta) / \mathrm{d} \theta \cdot \partial \theta / \partial \mathrm{z}
\end{aligned}
$$

のように表せる ${ }^{9)}$. 
以上のことから，楴固めた泥岩材料の体積含水率 $\theta$ と $\mathrm{D}(\theta)$ および $\mathrm{K}(\theta)$ の関係がそれぞれ明らかであるなら ば，式(8)を解くことによって，体積含水率 $\theta$ の時間的 および場所的な変化を評価することができる。その結果， 式(5)および $\mathrm{n}=\left(\mathrm{n}_{0}+\varepsilon_{z}\right) /\left(1+\varepsilon_{z}\right)$ の関係を用いる ことによって，締固めた泥岩材料中の任意の位置につい て，水浸後の任意な経過時間での飽和度とひずみ量を評 価でき, 盛土体の水浸沈下の経時的変化を求めうること になる。

\section{3. 室内試験}

締固めた泥岩材料の水浸沈下特性を理論的に取り扱う 方法として，上記のような力学モデルを構築した。この モデル式に含まれる力学パラメータを特定するためには， 然るべき室内試験を行い，それに関連した力学関係を捉 えることが不可欠である．例えば，締固めた泥岩材料の 水分拡散倸数 $\mathrm{D}(\theta)$ を求めるためには, $\mathrm{D}(\theta)=\mathrm{K}(\theta)$ $/(\mathrm{d} \theta / \mathrm{d} \phi)$ の関倸があるので, 体積含水率 $\theta$ と毛管ポテ ンシャルヘッド $\phi$ の関係ならびに不飽和透水倸数 $\mathrm{K}(\theta)$ との関倸をそれぞれ知る必要がある．前者については， 含水比 $w$ は $\theta \cdot \rho_{w} / \rho_{d}$ でもって表せるので, 含水比 $w$ とサクション p F $(=\log (-\phi))$ の関係曲線すなわち水 分特性曲線を求めることによって明らかにできる（ここ に， $\rho_{d}$ と $\rho_{w}$ はそれぞれ締固めた泥岩材料の乾燥密度之 水の密度である）。したがって，締固めた泥岩材料につ いて，p F 試験を実施しなければならない。また，後者 の関係を知るためには，不飽和透水試験が必要になる. さらに式(5)に含まれる変形倸数 $\mathrm{E}_{c}$ を知るためには， 吸水過程を考虑しながら，作用応力レベルでの圧縮試験 を行う必要がある。なお，いずれの力学関係あるいはパ ラメ一タも材料の状態によって大きく変動するので，楴 固めた泥岩材料と同じ粒度，含水量および密度を保有す る供試体について試験を行うことが重要である。別途， 理論解析の妥当性を検証するために，水浸沈下試験を実 施することになる，以下に，試験に関連した事項を概述 しておく

\section{（1）泥岩試料の採取と基本的性質}

本研究で用いた泥岩試料は, 山梨県のグリーンタフ地 域を形成する新第三紀・御坂層群ならびに富士川層群の うち，代表的な泥岩優勢層である「桃ノ木累層」および 「身延累層」からそれぞれ採取した「勝坂泥岩」と「身 延泥岩」と呼称されるものである。採取位置はそれぞれ 南巨摩郡下部町平松地内および波高島地内であり，その 泥岩の堆積年代は地質学上，それぞれ今から約 2,000 万 年前（新第三紀・中新世前期）および約 800 万年前（新 第三紀・鮮新世前期）であると推定される.

泥岩試料の基本的性質を明らかにするために，「密度 試験」，「スレーキング試験」および「破砕試験」等を 行った。それぞれの試験方法については，その試験の意
表一 1 用いた泥岩試料の基本的性質

\begin{tabular}{|c|c|c|}
\hline 試料の名称 & 勝坂泥岩 & 身延泥岩 \\
\hline 自然含水比 （\%) & 15.5 & 9.7 \\
\hline 真比重 & 2.69 & 2.73 \\
\hline 乾燥密度 & 1.94 & 2.09 \\
\hline 間隙率 & 29.1 & 23.6 \\
\hline スレーキング率（\%) & 1000.0 & 94.4 \\
\hline 破砕率 & 44.0 & 34.4 \\
\hline 最適含水比 & 17.2 & 14.5 \\
\hline
\end{tabular}

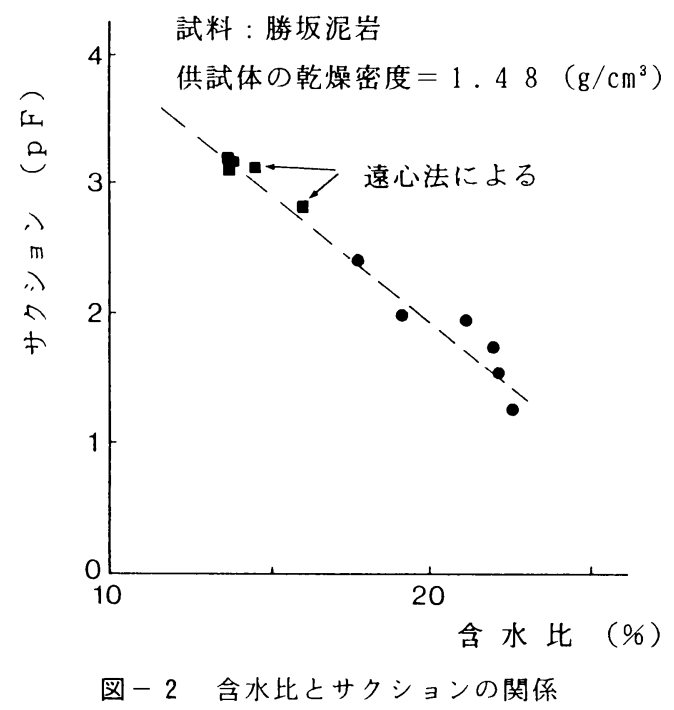

義等を含めて，別論文に記載してあるので，参照願いた $\left(^{6)}\right.$ 。試験から求めた泥岩試料の基本的性質を示すと, 表ー1のとおりである．スレーキング率は 94〜100\%で あり，破砕率は 34〜44\%であって，泥岩として典型的 な数值を示す.

力学試験としての p F 試験, 不飽和透水試験と圧縮試 験，ならびに検証実験としての水浸沈下試験にそれぞれ 用いる試料の粒度は，採取した泥岩を自然含水比に保っ たまま，ハンマーで粉砕し，それをふるいにかけて調整 したものであり, 粒径 $2 \mathrm{~mm} \sim 4.75 \mathrm{~mm}$ に相当するものと した。赛際は，これよりも粒度が粗い試料を対象にすべ きであるが，pF試験を始めとして，種々の試験に供す る供試体の大きさとの関係，また理論構築の前提条件に なる均質性を保持させるために，本研究ではこの粒度に 設定した。粒度調整した泥岩試料の締固め試験（JIS A 1210）から得られた最適含水比を合わせて表－1に示し ておくなお参考までに，水浸沈下に及ぼす試料粒度の 影響を調べるたに，粒度の異なる試料を 4 種類用意し， それぞれについて水浸沈下試験を行った。

\section{（2） p F 試験}

締固めた泥岩試料の水分特性曲線を知るために, p F 


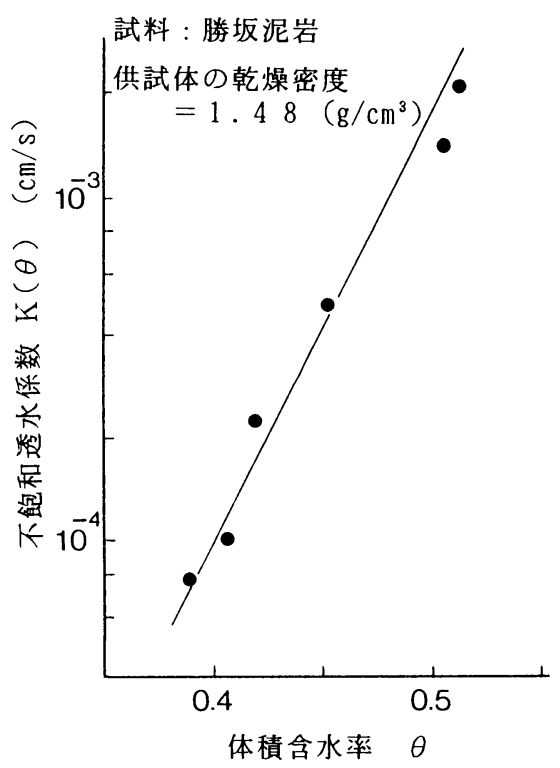

図一３締固めた泥岩試料の不飽和透水試験結果の例

試験を実施した。 p F 試験には, サクションの程度に応 じて吸引法や遠心法, 蒸気压法などがあるが, 比較的サ クションの小さい範囲での問題を扱う本研究では,「吸 引法」を用いて含水比とサクションの関倸を捉えること とした。図ー2は，締固めた泥岩材料に対して，p F 試 験から得られた両者の関係を表す一例である。一般に, 排水過程と吸水過程ではその関倸が異なることが知られ ている. 本研究は締固めた泥岩材料の水浸沈下現象を対 象にしているので，吸水過程に筊って関係を求めたこと は言うまでもない，これをみると，デー夕に多少のばら つきがあるが，狭い p F の範囲においては，水分特性曲 線すなわち含水比とサクションの関倸曲線はほぼ直線で もって近似できることが分かる。ここで，水分特性曲線 をあえて直線近似する理由は解析を容易にしたいために すぎない，なお図中の p F = 2.8 以上については，遠心 法によって求めた結果を参考までに併記したものである.

\section{（3）不飽和透水試験}

不飽和状態にある泥岩試料の透水倸数を求めるために は，土壌物理学の分野で考案されている「不飽和透水試 験」を行う必要がある。幾つかの試験法が提案されてい るが, 大別すると, 定常法と非定常法がある。本研究の 水浸沈下試験では一定の正圧を負荷して土中水の浸透を 図る方法を採るために，その条件に合わせる意図をもっ て定常法のうちの加压法を採用した。供試体の乾燥密度 が一定した $1.48 \mathrm{~g} / \mathrm{cm}^{2}$ になるよう静的に締固めた泥岩 試料の体積含水率 $\theta$ と透水倸数 $\mathrm{K}(\theta)$ の関倸を求めた例 を図一 3 に示しておく。これをみると， $\mathrm{K}(\theta)=\mathrm{c} \theta^{m}$

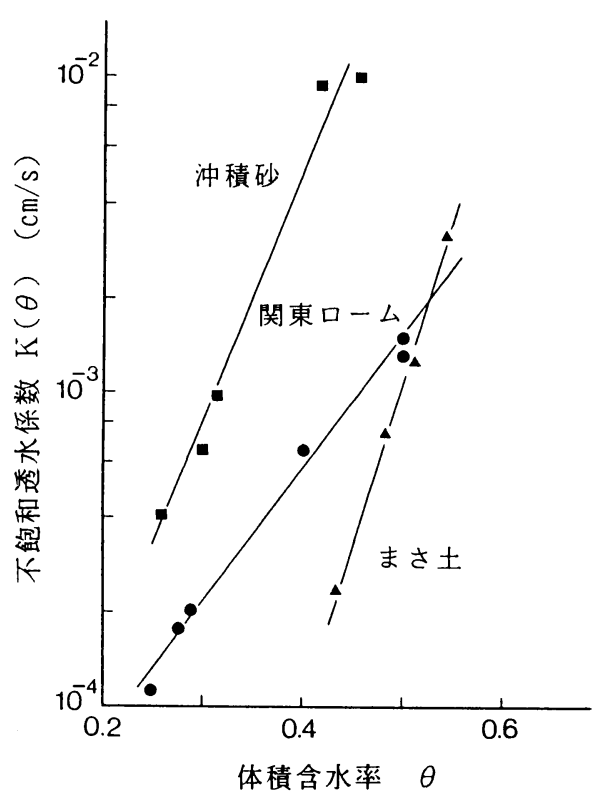

図-4各種不飽和土の透水試験結果

表一2 不飽和透水試験に用いた試料の基本 的性質亡供試体の密度

\begin{tabular}{|c|c|c|c|}
\hline \multirow{2}{*}{$\begin{array}{c}\text { 基本的性質 } \\
\text { 之乾燥密度 }\end{array}$} & \multicolumn{3}{|c|}{ 試 料 名 } \\
\cline { 2 - 4 } & 関東ローム & 沖積砂 & まさ土 \\
\hline 土粒子密度 $\left(\mathrm{g} / \mathrm{cm}^{3}\right)$ & 2.86 & 2.65 & 2.68 \\
\hline 有効径 $(\mathrm{mm})$ & 0.74 & 1.33 & 1.31 \\
\hline 均等係数 & 29.2 & 4.4 & 6.8 \\
\hline 塑性指数 & 36.4 & - & \\
\hline 乾燥密度 $\left(\mathrm{g} / \mathrm{cm}^{3}\right)$ & 0.74 & 1.33 & 1.31 \\
\hline
\end{tabular}

の関倸がほぼ認められる。なお参考までに，他の種類の 不飽和土に対する同様な試験結果を合わせて図ー4に示 しておく（試料の基本的性質および供試体の密度は表一 2 のとおりである).

\section{(4) 圧縮試験}

楴固めた泥岩試料の側方拘束状態下での変形係数 $\mathrm{E}_{c}$ を求めるために，圧密試験装置（オエゾメータ）を利用 した压縮試験を行った。まず，含水比を調整した泥岩試 料を圧密容器に入れて, 所定の乾燥密度になるように静 的荷重を順次增大させ，供試体を作成した。 その後，荷 重を作用させたままで供試体を水浸させ，水浸状態で增 分荷重を与えた。このような圧縮試験から得られた載荷 重とひずみの関係の例を図一5に示しておく，一般に， 変形倸数 $\mathrm{E}_{c}$ は応力レベルによって変化するので, 压縮 試験での荷重は水浸沈下試験での作用応力に対応するも のを与える必要がある．また $\mathrm{E}_{c}$ の值は水浸前後で若干 


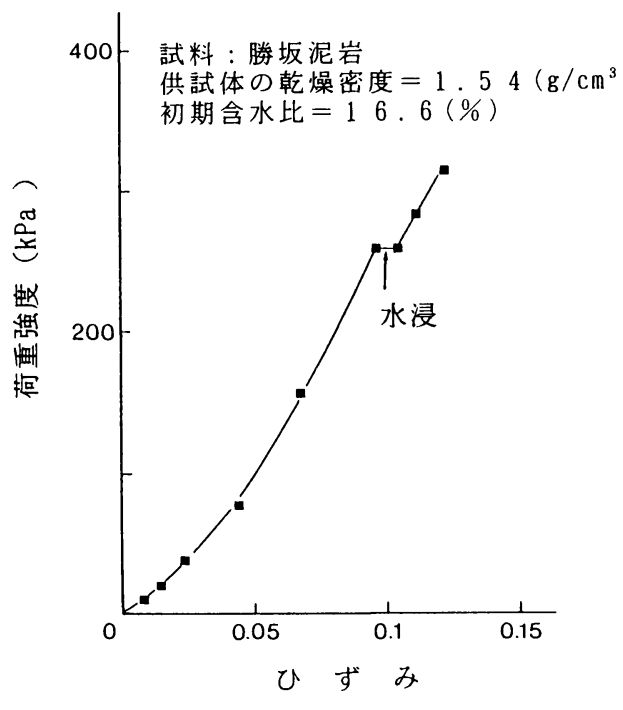

図ー5 締固めた泥岩試料の圧縮試験結果の例

変動するので，解析においてその平均値を用いるか，水 浸後の值を用いるかは，その選択に注意を要する．本研 究では, 水浸後の $\mathrm{E}_{c}$ が水浸沈下量に強く影響すると考 えられるので，それを用いることにした。また参考まで に，図ー5の試験と同じ条件下で行われた圧縮試験の途 中段階において測定された水浸前後での供試体試料の粒 度を図一6に示しておく．水浸に伴って試料の細粒化が 生じている様子が分かる。

\section{（5）水浸沈下試験}

締固めた泥岩試料の水浸沈下特性を明らかにするため に，解析モデルを構築したが，その妥当性を検討するた めに，幾つかのケースについて水浸沈下試験を試みた。

ある一定の含水比 $w$ （勝坂泥岩では約 $17 \%$ ，身延泥 岩では約 14\%）を有する泥岩試料を直径 $15 \mathrm{~cm}$ のール ド内に入れて, 静的荷重 $\mathrm{p}$ の作用のもとで締固め, 個 々に異なった空気間隙率 $\mathrm{V}_{\boldsymbol{a}}(=10$ ２5\%) を有する供 試体を作成した。なお，供試体の高さは $2 \mathrm{~cm}$ か $10 \mathrm{~cm}$ の籁囲内で任意に変えることにした，貯水容器の水位を 一定に保たせながら，載荷重 $\mathrm{p}$ を作用させたままで供 試体全体を水浸させ, 供試体底面からの水の浸透を許し て，その後に継続的に発生する供試体の沈下量を測定し た。なお，供試体底面での水压を一定に保たせた理由は， 不飽和透水試験で供試体両端面に対する加压を一定とし た条件にできるだけ合わせようとしたためである．図一 7 は, 粒径 $=19.0 \sim 37.5 \mathrm{~mm}$ という粒度の粗い試料を対象 とした場合における典型的な水浸沈下試験結果を示す.

この結果を含めて全体的に見られる特性は次のとおりで ある。 まず，水浸沈下量の時間的な変化については，压 密沈下のそれとほぼ同様な関倸が得られる。ただし，空

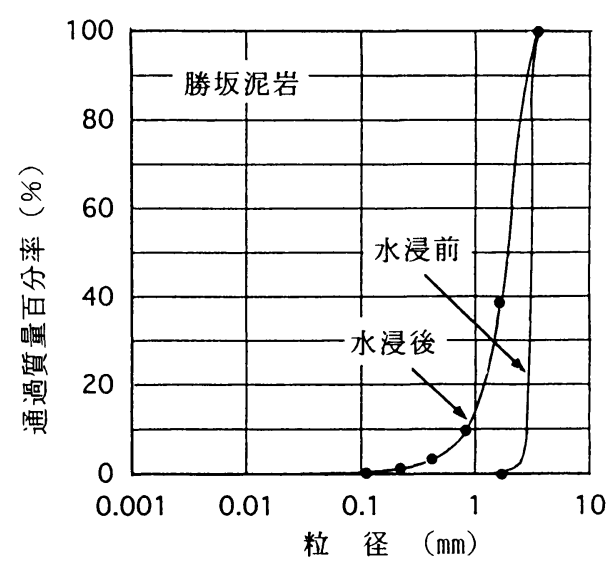

図一 6 水浸前後における泥岩試料の粒度の比較

供試体の初期高さ $=10 \mathrm{~cm}$ 初期含水比 $=14.2 \%$

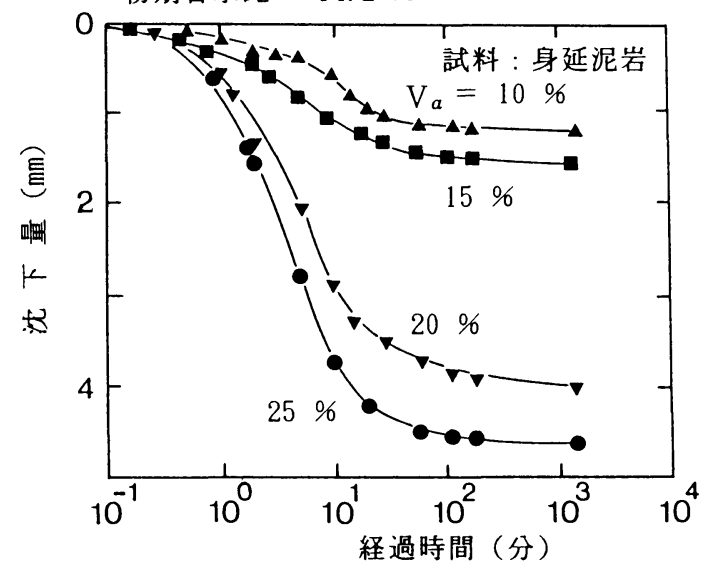

図一 7 締固めた泥岩試料の水浸沈下試験結果

気間隙率が $\mathrm{V}_{a}=10 \% ， 15 \%$ ように小さい供試体では, 水浸後に比較的小さい压縮沈下が発生し，その進行が時 間の経過のなかでほぼ終息に向かう。一方, 空気間隙率 がある一定の数值（図ー7では，15〜20\%の間の数值） を超えると，沈下の発生量が急激に増大して，空気間隙 率の増加に対して必ずしも単純に増すわけではないこと が分かる。この理由としては, 空気間隙率が小さい場合 は、構造骨格が安定しており, 水浸に伴う泥岩粒子の軟 弱化が主に水浸沈下に関与するのに対して, 空気間隙率 が大きい場合は，骨格のコラプスと粒子の軟弱化の両方 が起こって，それが水浸沈下に反映されるためと推測さ れる。

また，泥岩試料の粒度が水浸沈下に及ぼす影響を調へ るための試験を実施した，水浸後 24 時間が経過した時点 での沈下量について，その結果を図ー8に示しておく. これをみると, 水浸沈下量は泥岩試料の粒度によって大 きく影響を受け，粒度が粗いほど相対的に增大すること， 


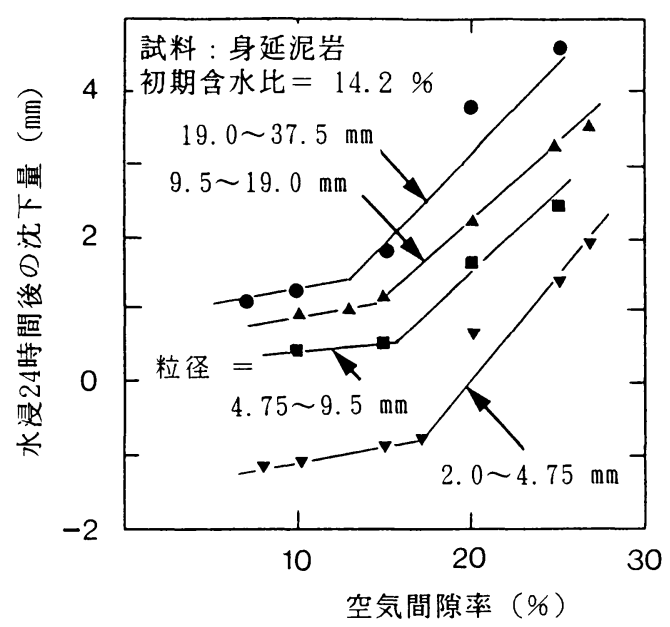

図ー8 粒度の異なる泥岩試料に関する空気間隙率 と水浸 24 時間後の沈下嘼の関係

粒度の細かい供試体では, 空気間隙率が小さい場合に, むしろ膨潤が起こることが分かる。これらの実験事実か ら，水漫に伴って発生するスレーキング現象によって泥 岩粒子が細粒化を起こし，その程度が粒度の粗い試料ほ ど顕著であること，また粒度の粗い試料ほど供試体内で の個々の間隙が大きく，それを埋めるように細粒化した 泥岩粒子が移動を起こし, 結果的に沈下量が增大するこ と, 粒度が細かい試料では, 泥岩粒子のスレーキングよ りも膨潤が相対的に卓越することなどが推定できる.

なお，図一8の結果から判断すると，前述した解析モ テルは, 均質性が高い細粒試料を対象とし，水浸沈下の 発生を前提とするものであるから，その適用範囲は粒径 が 2.0〜 4. $75 \mathrm{~mm}$ であり，かつ沈下を発生させる $20 \%$ 以上 の空気間陌率をもつ試料の場合に限定されよう.

\section{4. 計算結果と実験結果の比較および考察}

ある一定の空気間隙率を有する供試体を対象にして水 浸沈下試験を実施するとともに，それに対応する条件の もとで 2 章で展開した理論に基つき数値計算を行い，両 者の比較から, 理論の妥当性について検討した.

\section{（1）数値計算の方法}

式(8)に含まれる不飽和透水倸数 $K(\theta)$ は，図一 3 ま たは図ー4の不飽和透水試験結果から明らかなように, $\mathrm{K}(\theta)=\mathrm{c} \theta^{m}$ として表せる. また, 図一 2 のような含 水比とサクションの関倸, すなわち水分特性曲線は本研 究で扱う含水比の範囲において直線近似ができるので，

$$
\begin{aligned}
\mathrm{d} \theta / \mathrm{d} \phi & =(\mathrm{d} \theta / \mathrm{d} w)(\mathrm{d} w / \mathrm{d} \phi) \\
& =\left(\rho_{d} / \rho_{w}\right) \cdot \exp (2.3 \beta w) /\left(-2.3 \beta \psi_{0}\right)
\end{aligned}
$$

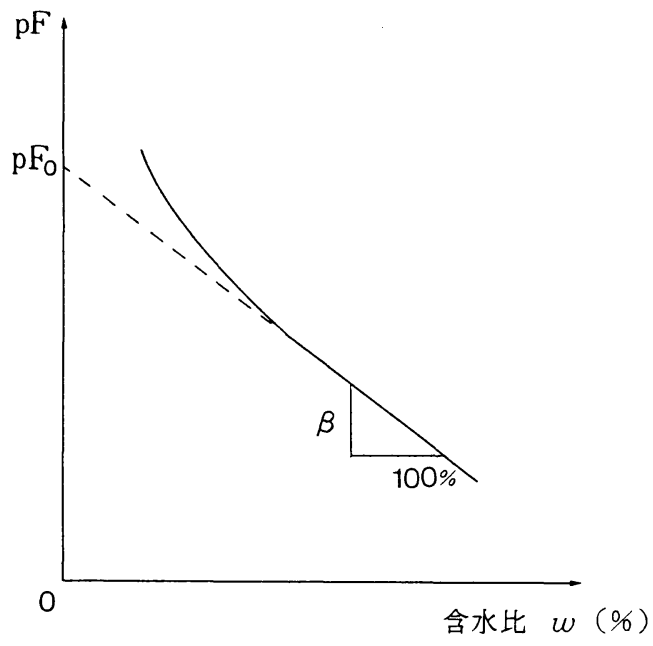

図一9 水分特性曲線の直線近似化

として表せる。なお，式中の $\beta$ は直線近似した水分特性 曲線の絶対勾配であり，またその含水比 $w=0$ に対応す るサクションを $\mathrm{p} \mathrm{F}$ 。とすると， $\phi_{0}$ は $\phi_{0}=-10^{\mathrm{pF}}$ $(<0)$ である(図一 9 を参照).よって, $\mathrm{D}(\theta)=\mathrm{K}(\theta)$ $/(\mathrm{d} \theta / \mathrm{d} \psi)$ は.

$$
\mathrm{D}(\theta)=\mathrm{A} \theta^{m} \cdot \exp (-\alpha \theta)
$$

になる．ただし， $\mathrm{A}=-2.3 \beta \phi_{0} \mathrm{c}\left(\rho_{w} / \rho_{d}\right)$ である. これより, 供試体高さを $\mathrm{H}$ とて, 補助変数 $t^{\prime}=t /$ $\mathrm{H}^{2}, \mathrm{z}^{\prime}=\mathrm{z} / \mathrm{H}$ を用いると, 式(8)は，

$$
\begin{aligned}
\partial \theta / \partial \mathrm{t}^{\prime}= & \mathrm{D}(\theta)\left[(m / \theta-\alpha)\left(\partial \theta / \partial z^{\prime}\right)^{2}\right. \\
& +\left(\partial^{2} \theta / \partial z^{\prime 2}\right)+\left(\mathrm{c} m \mathrm{H} \theta m^{-1} /\right. \\
& \left.D(\theta))\left(\partial \theta / \partial z^{\prime}\right)\right]
\end{aligned}
$$

となる。これを差分式に変換して, 境界条件の(1) $\mathrm{t}^{\prime}=$ 0 で $\theta=\theta_{0}=\left(\rho_{d} / \rho_{w}\right) w_{i}$, (2) z $z^{\prime}=0$ で $\theta=\theta_{f}$ $=\left(\mathrm{n}_{0}+\varepsilon_{z f}\right) /\left(1+\varepsilon_{z f}\right),(3) z^{\prime}=1$ で $\partial \theta / \partial z^{\prime}$ $=0$ のもとで差分計算を行えば, 任意の時刻と位置で の体積含水率 $\theta$ が求まる. なお， $w_{i}$ は供試体の初期含 水比である.また, $\mathrm{n} 。$ は供試体の初期間隙率であって,

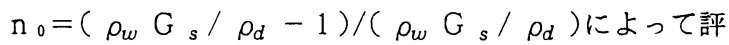
価できる。また， $\mathrm{t}^{\prime} と \mathrm{z}^{\prime}$ の刻みについては，収束条件 を満たす様々な場合について差分計算を行い, 計算結果 が刻みの大きさにかかわらず一定になるもののうち，最 も大きい刻みを用いた。 $\theta$ が求まれば, 式(5)ならびに 間腺率 $\mathrm{n}$ と圧縮ひずみ $\varepsilon_{z}$ の関係式を合わせて用いる ことにより, 水浸後での任意時間における供試体内の飽 和度と圧縮ひずみ量が求まり，水浸沈下量を算定できる。 ただし，境界条件 (2)で用いられる $\theta_{f}$ は事前には分か らないという問題があるので，まず， $\theta_{f}=\mathrm{n} 。$ と仮定 して水浸沈下の全過程について差分計算を行い, 得られ 
表 - 3 数値計算に用いた定数（勝坂泥岩）

経過時間（分）

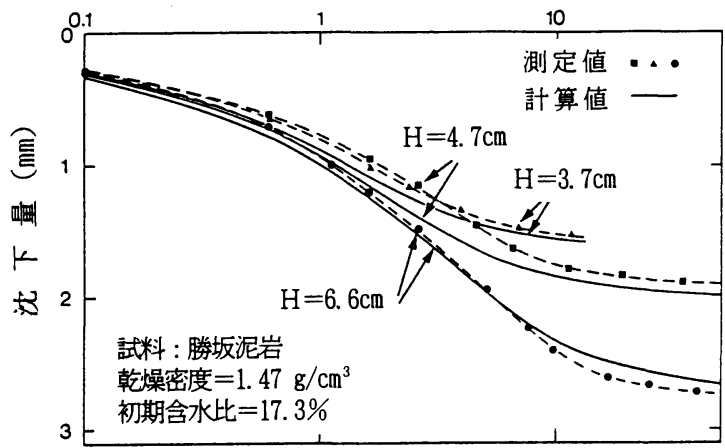

図-10 水浸沈下に関する測定値と計算値の比較 （供試体の高さを変化）

経過時間（分）

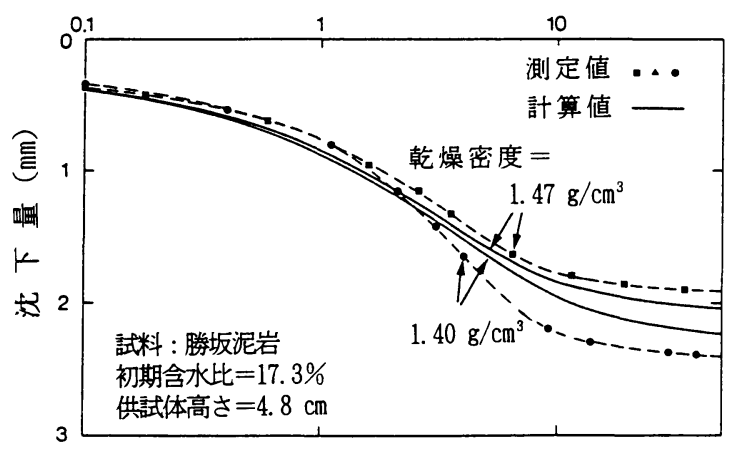

図-11 水浸沈下に関する測定值と計算値の比較 （供試体の密度を变化）

た $\varepsilon_{z f}$ を用いて $\theta_{f}=\left(\mathrm{n}_{0}+\varepsilon_{z f}\right) /\left(1+\varepsilon_{z f}\right)$ から修 正を施し，また水浸沈下の全過程の差分計算をやり直す という具合にして, 解の整合性が確認できるまで差分計 算全体を数度綝り返し, 結果として精度の高い数値計算 を行えるようにした。

\section{（2）計算値と測定値の比較とその考察}

まず, 乾燥密度が $1.40 \mathrm{~g} / \mathrm{cm}^{3}$ または $1.47 \mathrm{~g} / \mathrm{cm}^{3}$ (空気 間腺率で $23.3 \%$ または $20.0 \%$ ）であるような比較的大 きい水浸沈下が発生する場合について，水浸沈下の測定 值と計算値の両者を比較すると，図一10および図ー11の ようになる。なお，計算に用いた諸パラメー夕の数値は すべて前述の室内試験から求めたものであり，その一覧 を表ー3に示しておく。

図一10は, 含水比 $=17.3 \%$ (JIS A 1210による最適含 水比）のもとで乾燥密度が $1.47 \mathrm{~g} / \mathrm{cm}^{3}$ （空気間隙率では

\begin{tabular}{|c|c|c|}
\hline \multirow[b]{2}{*}{ 供試体の力学状態を表す定数 } & \multicolumn{2}{|c|}{ 乾燥密度 $\left(\mathrm{g} / \mathrm{cm}^{3}\right)$} \\
\hline & 1.40 & 1.47 \\
\hline 初期間隙率 & 0.48 & 0.45 \\
\hline 初期体積含水率 & 0.24 & 0.25 \\
\hline 水分特性曲線の絶対勾配 $\beta(\%)$ & 24.7 & 21.5 \\
\hline 含水比 0 の対応サクション $\mathrm{pF}$ 。 & 6.91 & 6.30 \\
\hline $\mathrm{Ec}(\mathrm{MPa})$ & 3.2 & 5.4 \\
\hline 透水特性を表す係数 $\mathrm{c}(\mathrm{cm} / \mathrm{s})$ & 943 & 670 \\
\hline 透水特性を表す覀数 $\mathrm{m}$ & 13.5 & 13.6 \\
\hline
\end{tabular}

20.0\%)になるよう静的に締固めた泥岩材料の供試体に ついて，その高さを変えた場合の経過時間と水浸沈下量 の関係を表す。また図ー11は，供試体の厚さを一定にし て, 供試体の乾燥密度を $1.47 \mathrm{~g} / \mathrm{cm}^{3}$ と $1.40 \mathrm{~g} / \mathrm{cm}^{3}$, すな わち空気間隙率で $20.0 \%$ と $23.3 \%$ に設定した場合の同 様な関倸である。これをみると全体的に, 測定值と計算 值の両者はほぼ同じような水浸沈下特性を示しているこ とが分かる. すなわち, 最終的な水浸沈下量は両者でほ ぼ一致した結果になること, 沈下の経時的な進行につい てはその変化特性が全体的にみて両者で類似した様相に なっていること, 半面, 変化速度については計算結果と 実験結果で僅かながら相異する部分があることなどが分 かる. 沈下の速度に影響する要因は供試体内での間隙水 の浸透性にあるので, 水浸沈下試験での間隙水の浸透機 構が不飽和透水試験のそれと若干異なることが考えられ る. このため, 水浸沈下試験での動水勾配と透水試験で 設定する動水勾配を等しくしたり, 供試体の密度や載荷 重強度などが同じ条件になるよう細心の注意を払ったが， 結局は差異を解消することはできなかった。ここには， 泥岩のように水浸に伴ってスレーキングすなわち粒度変 化を起こす材料または粒子骨格のコラプスが発生する材 料に対して, 従来の不飽和浸透理論をそのまま適用する ことに限界があるのかも知れない。しかし，このことに 関して明確な見解を打ち出すには, 今後のさらなる研究 が必要であろう.

また，展開した理論の妥当性を局部的な観点から検討 するために，水浸沈下過程の途中段階における供試体内 部の含水量の分布状態を調べた。図ー12は, 供試体内部 の各点における含水比の測定值と同じ過程段階での計算 值を比較したものである. 両者の差異が認められる部分 が一部存在するが, 全体的には良い一致がみられ，この 点については理論の妥当性がほぼ確認できると言えよう.

以上のような理論結果と実験結果の両者の比較から, 構築された理論は, 全体的にはほぼ泥岩材料の水浸沈下 現象を説明しうるものになっていると考えられる. しか し, 今回の解析では, 間隙空気圧を無視し, 不飽和パラ メータを $\chi \leftrightharpoons S_{r}$ で近似しているので, この点について 

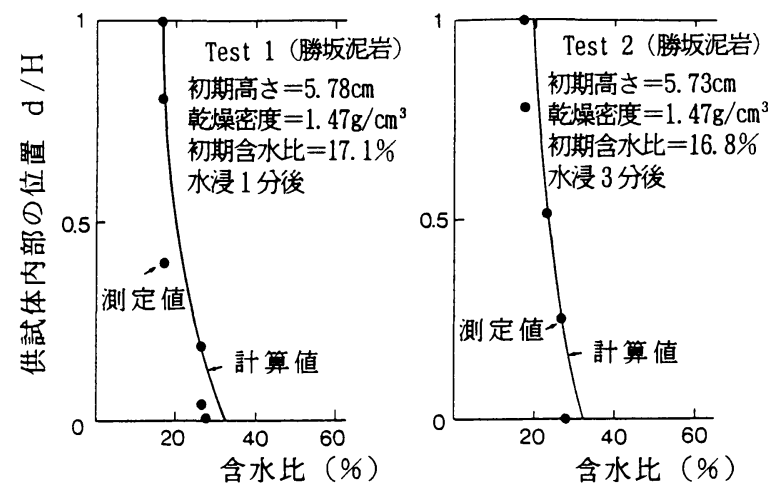

図ー12 水浸沈下試験中における含水比の測定値之計 算値の比較

は今後の改善が必要であると考える。

また本論では，構築理論の妥当性を検証することを目 的の一つとしたために，土質パラメー夕の数値を決定す るための各種室内試験ができるだけ容易に実施されるよ うに供試体の空気間隙率が比較的大きい場合，すなわち 比較的大きい水浸沈下が発生する条件のもとでの検討を 中心に行った. 今後は, 締固めた泥岩材料が小さ空気 間腺率を有して水浸沈下をあまり起こさない場合やむし ろ膨潤を起こす場合を含めて，より高い視点から空気間 隙率が水浸変形特性に及ぼす影響を理論解析的に明らか にしていく必要がある。

\section{5. 結 論}

本研究においては, 典型的な軟岩である泥岩を盛立て 材料として用いた場合に工学的問題を引き起こす恐れの ある水浸沈下現象に注目して，その発生機構を考虑した 理論の構筑を行うとともに, 各種室内試験を実施して, 理論結果と実験結果を比較・検討し，水浸沈下に関する 一般的特性を追究した。その結果, 下記のような結論を 得た。

（1）締固めた泥岩材料に発生する水浸沈下現象につい
て，不飽和浸透問題と不飽和体の変形問題を結び付ける 解析手法により理論的に追究し，解析モデを構築した。

（2）室内実験における測定值と構築した理論に基つくく 数値計算値との比較から，締固めた泥岩材料の空気間隙 率が比較的大きい場合について, 理論の妥当性を検証し た，その結果, 理論によって, 水浸沈下および含水量の 経時的な变化を定性的かつ定量的にほぼ説明できた。

（3）締固めた泥岩材料の粒度は水浸沈下に大きく影響 して，粒度が粗いほど沈下量が相対的に増大すること， また粒度が細かい場合には，空気間隙率が非常に小さく なるまで締固めると膨潤が発生することが水浸試験結果 から明らかになった。

なお本研究では, この種の研究の端緒として, 理論の 構築之解析が比較的容易にできるように，岩粒子の均等 性が高く，粒度の細かい泥岩材料を対象の中心に据えた。 実際には，泥岩塊材料の粒度は多岐にわたるので、その ような場合に対する研究を発展させる必要がある。

\section{参考文献}

1) 土質工学会編：日本の特殊土（土質基礎工学ライブ ラリ-10),pp.314-342,1974.

2 ) 中岡時春, 望月秋利, 阪口理：堆積軟岩を用いた 盛土造成工事の施工管理，堆積軟岩による盛土の工 学的諸問題に関するシンポジウム,pp.205-212,1995.

3 ）たとえば,土質工学会編：土質工学用語辞典,p.101, 1985.

4 ）福田護, 中沢重一：盛土地盤の浸水に伴う沈下と その解析について, 土質工学会論文報告集, 第17巻, 第2号, pp.65-73,1977.

5 ）野田 耕，西 勝：軟岩盛土の水浸沈下に関する研 究, 土木学会論文集,第391号,pp.77-86,1988.

6 ）村上幸利：締固めた軟岩材料の力学的安定性に及ぼ す岩の性質と締固め度の影響，土木学会論文集，第 511号,pp.109-116,1995.

7 ) 島 博保，今川史郎：スレーキング材料(ぜい弱岩) の压縮沈下と対応策，土と基礎，第28巻, 第7号, pp. 45-52, 1980 .

8 ）入江恒爾, 荒井克彦, 竹内成和：不飽和泥岩の吸水 膨張機構，土質工学会論文報告集，第22巻,第2号。 pp. 142-148,1982.

9 ）八幡敏雄：土壤の物理,東京大学出版会,pp.71-108, 1975 .

(1997. 5.22 受付)

\title{
FUNDAMENTAL STUDY ON SETTLEMENT CHARACTERISTICS OF COMPACTED MUDSTONE MATERIALS SUBJECTED TO SUBMERGENCE
}

\section{Yukitoshi MURAKAMI}

\begin{abstract}
When mudstone is employed as a fill material, the slaking or degeneration of the material often causes the engineering problem such as excessive surface settlement or slope failure of an embankment. The present study is theoretically and experimentally concerned with the settlement characteristics of compacted mudstone materials subjected to submergence, by considering the mechanical properties of compacted mudstone and the mechanism of unsaturated seepage flow. Although there remains the problem that the conditions treated in this study are strongly idealized and restricted, it has been found that the theory can explain the time history of both settlement and moisture content of a compacted mudstone material subjected to submergence. Moreover, some settlement characteristics has been revealed from the experimental results.
\end{abstract}

